\title{
The Root-Nodules of the Cycadaceae.
}

\author{
BY \\ ETHEL ROSE SPRATT, D.Sc., A.K.C. \\ University of London, King's College.
}

With Plate XXIX.

$\mathrm{T}$

HE Cycadaceae are a group of special interest, owing to their retention of a greater number of primitive characters than are possessed by any other living group of Gymnosperms. Representatives of this group probably existed during the Mesozoic Period and were very widely distributed. The living cycads are represented by five eastern genera: Cycas, Encephalartos, Stangeria, Macrozamia, and Bowenia, and four belonging to the western hemisphere : Zamia, Microcycas, Dioon, and Ceratozamia, all of which are tropical or subtropical. In all the genera with the exception of the monotypic genus Microcycas, which is confined to $\mathrm{Cuba}$, and has not been examined by the author, there are in addition to the primary tap-root numerous small secondary roots, some of which form the so-called rootnodules.

These structures have been described as 'Coralline roots' in Cycas, where they occur abundantly immediately below the surface of the soil and protruding above it. Reinke described them as special organs for aeration, Schneider suggested a symbiotic association, and Life isolated from them an Alga and some Bacteria, and believed them to be concerned in the assimilation of nitrogen as well as aeration. More recently Zach states that they are not symbiotic, but contain a fungal parasite against which the cells react as a phagocyte.

Amongst non-leguminous plants it is now recognized that the Elaeagnaceae, Myricaceae, Podocarpineae, and the genus Almus have root-nodules, which are definitely concerned with nitrogen assimilation. With these the Cycadaceae must be associated, because Bottomley has isolated from the nodules of Cycas not only Bacillus radicicola but also Azotobacter, both of which organisms are known to assimilate atmospheric nitrogen. They are, however, of special interest because in their cortex a very definite green ring, the algal zone, is produced by the presence of an Anabaena, which has been described by the author. 
The first part of the present series of investigations was carried out with material of Cycas circinalis and Encephalartos Hildebrandtii kindly supplied by the Curator of Chelsea Physic Gardens ; and was extended to comprise the genera Stangeria, Macrozamia, Zamia, Ceratozamia, Dioon, and Bowenia, through the kindness of the Director of the Royal Botanic Gardens, Kew, both of whom I desire to thank.

Root-nodules have been found to occur throughout all the cycadean genera, and as in other non-leguminous plants they are perennial modified lateral roots which have diverged from their normal growth owing to their having been infected with the nitrogen-fixing organism Bacillus radicicola.

In Cycas circinalis they are confined to the surface of the soil and the layers immediately below. It has, however, been ascertained that the lower roots frequently become infected with Bacillus radicicola, which penetrates the root-hairs and enters the cortex, where its presence stimulates the root to become negatively geotropic (Fig. I), and when near the surface of the soil the tip becomes swollen and subsequently profusely branched, giving rise to a coralloid mass (Fig. 2). Large masses of these structures are visible on the surface of the soil, and they characteristically contain a very definite green ring, the algal zone. The same conditions occur in $C$. revoluta and $C$. seemanni, but some species in cultivation at Kew have not developed these nodules very abundantly.

Encephalartos Hildebrandtii and all the species cultivated at Kew exhibit a similar phenomenon, but the individual nodules are larger, and thus, although the branching is very profuse, the clusters are less dense (Fig. 3).

Examination of a large number of nodules from both Cycas and Encephalartos showed that the nodule tip may become quite large and even branched several times, while no algal zone is present (Fig. 3, a, b). The Alga therefore lives in the soil, and must at some period gain an entrance to the nodule. The roots which have become negatively geotropic have Bacillus radicicola in their cortical cells, but they retain their normal appearance. Very soon, however, a ring of structures, apparently lenticels, is formed a little distance from the tip, which subsequently becomes swollen (Figs. I and $3 a$ ). The lenticels consist of large masses of very loosely arranged parenchymatous cells formed from the phellogen. They soon become infected with Bacillus radicicola and also Azotobacter, the latter at first making their way between the cells, and later entering them (Fig. 9). Gradually in the nodule, i. e. the portion above the ring of lenticels, the outer cells produced by the phellogen increase in size owing to infection with Bacillus radicicola, and are pushed apart by masses of Azotobacter, some of which subsequently penetrate into them, with the result that there is a zone on the outside of the nodule which contains the two nitrogen-fixing organisms associated together (Fig. 9). This zone extends from the basal lenticels 
nearly to the meristematic apex. In many cases Anabaena filaments are associated with these large loose outer cells, especially in the angles produced by the nodule branching (Fig. 9).

Other nodules have a very definite green algal zone traversing a corresponding area of the nodule, but enclosed by a few layers of cells (Fig. II). The three organisms Bacillus radicicola, Azotobacter, and Anabaena now all become concentrated in this area, which consists of a large air space inhabited by the Anabaena and Azotobacter, and traversed by elongated papillate cells connected with both the inner and outer tissues, thus keeping the zone intact, and being themselves rich in protoplasmic contents, and containing Bacillus radicicola (Fig. IO). The cortical cells between the algal zone and stele are remarkably free from infection, although some contain the two Bacteria, most of them are filled with starch grains or calcium oxalate crystals. Outside the algal zone is a very definite phellogen which produces a few layers of parenchymatous cells towards the zone, and a few very regular cells on the outside. The algal zone always begins very abruptly immediately above a lenticel, but at the apex of the nodule the Anabaena appear to make their way gradually between the cells into which also the Bacteria penetrate, thus continuing the growth of the zone with that of the nodule. Sometimes, however, it is localized to quite a small area, perhaps on one side of the nodule. Associated with its production is an extended development of lenticels at some portion of which the zone is always interrupted (Fig. II). In nodules without an algal zone only a basal ring of lenticels occurs, but where it is present they are produced in connexion with every branch and at quite frequent intervals on the branches themselves (Fig. 3). The nodule often branches dichotomously, but lateral branches also arise, particularly beneath the primary ring of lenticels, which may become nodules or lateral roots (Fig. 5).

Whilst visiting Kew Gardens, one of the Stangeria Schizodon plants was observed to have a piece broken from the pot quite near the bottom, and from this hole a number of roots upon which were numerous small nodules were seen to be emerging. This aroused the question whether the nodules in other members of the Cycadaceae were confined to the surface of the soil or not. Their formation here might have been induced by the exposure to light and air resulting from the presence of the hole, or it might be that they were more or less uniformly distributed throughout the pot. On inquiry the latter was found to be the case.

In Stangeria small nodules are produced all along the root, each of which branches dichotomously, and thus little clusters are formed (Fig. 4). Infection of the root with Bacillus radicicola occurs through the root-hairs, and these organisms infect the young lateral roots whilst they are traversing the cortex, and thus their growth in length is arrested, and they are stimulated to branch almost immediately they are free from the parent 
root. The root-tip may also develop a ring of lenticels and form the beginning of a cluster of nodules. At the base of the nodules which are produced laterally the phellogen becomes very active, and gives rise to a complete ring of lenticellular tissue (Fig. I2). Between this basal ring of tissue and the nodule large groups of Azotobacter and sometimes Anabaena collect, both of which are also associated with the outer cells of the nodule, as in Cycas and Encephalartos. As the nodule develops, other lenticellular areas may appear, which are very out-curved with a strong tendency to form a zone of parenchyma parallel with the surface of the nodule, and frequently small localized areas, containing the three organisms so characteristically associated with the outer cells, become completely enclosed (Fig. I3).

Nodules in which an algal zone is developed become very much elongated, always remaining very slender, and branching repeatedly (Fig. $4, b)$. In these nodules the zone occupies a larger proportion of the cortex, and is traversed by many more papillate cells than in Cycas and Encephalartos. The three symbiotic organisms extend through the outer cortex to the phellogen usually, and are often associated with the outer cells. Nodules have been examined which had enclosed, in addition to an algal zone, certain other areas of Algae and Bacteria on the surface. In branched nodules the two algal zones of respective branches have been found separated from one another by a band of meristematic tissue.

The nodules of Macrozamia Macleyi (Fig. 6) and M. Dennisoni resemble very closely those of Encephalartos in which no algal zone has developed, and no algal zone has been found in these nodules. Correlated with this is the scarcity of nodules on the surface of the soil in the plants at Kew. Their development corresponds with that described above, but the outer cells, in which Azotobacter and Bacillus radicicola are found together, are so large and loosely arranged that the surface of the nodule presents an uneven spongy appearance. In some cases the infection with Azotobacter extends well into the cortex throughout which Bacillus radicicola is distributed.

In Ceratozamia mexicana (Fig. 7), and Zamia lindeni (Fig. 5), the nodules observed remain quite small although branched, and are arranged very regularly in two rows along the root. In Ceratozamia large numbers are visible on the surface of the soil. A few roots of Bowenia spectabilis were also obtained upon which were some very young nodules. In these three genera Bacillus radicicola is present in the cortical cells of the root and nodule. The basal phellogen produces an envelope of parenchymatous tissue as in Stangeria, and in some of the older nodules a second phellogen appears in that area inside the old one. The loose outer cells usually have Azotobacter associated with them, but no Alga has been found present in these genera.

The roots of Dioon spimulosum and Dioon edule produce successive 
layers of cork which gradually become split and peel off. The cells themselves are rich in tannin. In addition to, and perhaps correlated with, this somewhat extensive development of periderm, large fan-shaped masses of parenchyma are produced at frequent intervals on the roots. There is a greater development of cells resembling lenticellular complementary cells than has been observed elsewhere. Large masses are present at the base of all lateral roots and also nodules (Fig. I4), which are abundant on roots a little below the surface of the soil. The nodules are repeatedly branched; in some cases two rows of small branches are produced from a central portion, but eventually large spherical masses are produced (Fig. 8). These small nodules show the typical structure described above where no algal zone is present. In addition to these, very much enlarged root-tips are visible on the surface of the soil, which also contain Bacillus radicicola and have a thick periderm in which numerous very large lenticels are developed. One nodule was obtained which had a definite algal zone (Fig. 8, $b$ ) occupying a large area. Since only those nodules, to which the sun's rays can penetrate, can contain a living green organism, it seems probable that it is in the swollen tips which reach the surface that the Anabaena finds its home.

From these investigations the conclusions have been reached that rootnodules are universally present throughout the Cycadaceae, and they are primarily produced by infection with Bacillus radicicola, and are therefore concerned with nitrogen assimilation. They are adapted to utilize both the nitrogen-fixing organisms Bacillus radicicola and Azotobacter which are known to fix a greater quantity of atmospheric nitrogen per unit of carbohydrate when growing together than separately.

There is also sometimes a fourth symbiont present-the Anabaena. It is not, however, essential to the formation of the nodule, since in Macrozamia, Zamia, Ceratozamia, and Bowenia it has not been found, and only in one instance in Dioon. The presence of lenticels is evidently correlated with the formation of the algal zone, since they are much more abundant on nodules in which it is developed, and the zone itself is always interrupted immediately below some part of the lenticel. These facts, together with the universal occurrence of a ring of lenticels, or a basal ring of parenchyma with an active phellogen, and the presence of Azotobacter and Anabaena amongst the outermost layers of cells, suggest very strongly that the outer layers of the original nodule become broken down to form the algal zone, and the phellogen of the basal and lenticellular areas is stimulated by the presence of the Anabaena to develop a zone of cells, parallel with the surface of the nodule, which gradually extends and forms a pro. tective layer. This is supported by $(a)$ the formation of the local enclosed areas on the surface of the nodule, containing the three organisms in Stangeria; $(b)$ the algal zone retaining a localized position in the nodule which has been observed in Cycas, Encephalartos, and Stangeria, and also 
(c) the separation of two algal zones by a meristem which has been-observed in Stangeria.

The Anabaena would naturally confine itself to an area not many cells deep, if photosynthesis were to go on, because of its dependence on light, the intensity of which must be rapidly diminished as it passes through the overlying cells. It is also impossible for the algal zone to be developed in nodules situated far below the surface of the soil, to which the photosynthetic rays of the sun cannot penetrate. In those cases in which the algal zone appears to be entirely absent it may be due to the method of cultivation, possibly to the absence of the specific Anabaena from the soil, since nodules are produced so abundantly without it and correspond very closely with those of other genera in which it afterwards develops. The algal zone is an area in which photosynthesis is taking place and probably attracts chemotactically the nitrogen-fixing organisms which require a carbohydrate as their source of energy. The three organisms thus collect together and work symbiotically, undoubtedly benefiting the cycad by the rich supply of elaborated material they produce.

In conclusion my thanks are due to Professor W. B. Bottomley for his sympathy and suggestions during the progress of these investigations.

\section{Summary.}

I. All the cycadean genera produce root-nodules which are perennial, modified lateral roots, repeatedly branched and typically forming large coralloid masses.

2. They are produced primarily by infection with Bacillus radicicola.

3. A whorl of lenticels or a continuous zone of loosely arranged parenchymatous cells is produced at the base of each nodule.

4. The outer cells always become pushed apart and infected by Azotobacter and, if suitable conditions prevail, by Anabaena also.

5. The presence of the Alga stimulates the phellogen to produce other lenticels, from which and the basal area a zone of tissue is produced which encloses the original outer cells in which are the Alga and Bacteria.

6. The algal zone is continuous, except immediately below the lenticels, extending from the base nearly to the meristematic apex.

7. The algal zone consists of a large air-space containing Anabaena and Azotobacter which is kept intact by papillate cells traversing it from both the inner and outer tissues.

8. Bacillus radicicola is chemotactically attracted to the algal zone; thus leaving the cortical cells in which large quantities of starch grains and sphaeraphides are deposited, and in Dioon, also tannin.

9. No algal zone has been observed in Macrozamia, Zamia, Ceratozamia, and Bowenia, but nodules are produced containing Bacillus radicicola and Azotobacter. 
10. The Cycadaceae, a group with many primitive characters, are the only nodule-bearing plants known, in which four organisms are associated together symbiotically, viz. two nitrogen-fixing Bacteria, an Alga, and the Cycad.

\section{BIBLIOGRAPHY.}

Bottomley, W. B.: The Cross Inoculation of the Nodule-forming Bacteria from leguminous and non-leguminous Plants. Report, British Association, I90\%.

: Some Effects of Nitrogen-fixing Bacteria
Plants. Proc. Roy. Soc., B., vol. lxxxi, I 909, p. 287. : The Root-Nodules of Myrica Gale. Ann. of Bot., vol. xxvi, i912.

Life, A. C.: The Tubercle-like Roots of Cycas Revoluta. Bot. Gaz., vol. xxxi, I90I.

Osborn, T. G. B.: The Lateral Roots of Aymleon radicans, and their Mycorhiza. Ann. of Bot., vol. xxiii, I909.

Reinke, J. : Parasitische Anabaena in Wurzeln der Cycadeen. Gött. Nachr., vol. cvii, I 872.

Schneider, A. : Mutualistic Symbiosis of Algae and Bacteria with Cycas revoluta. Bot. Gaz., vol. xix, 1894 .

Spratt, E. R.: Some Observations on the Life-history of Anabaena Cycadaceae. Ann. of Bot., vol. $\mathrm{xxv}, \mathrm{I} 9 \mathrm{II}$.

: The Morphology of the Root-tubercles of Almus and Elacagmus, and the Polymorphism of the Organism causing their Formation. Ann. of Bot., vol. xxvi, I9I2.

: The Formation and Physiological Significance of the Root-Nodules in the Podocarpineae. Ánn. of Bot., vol, xxvi, I9I2.

$\mathrm{Z}_{\mathrm{ACH}}, \mathrm{F}$.: Studie über Phagocytose in den Wurzelknöllchen der Cycadeen. Österreich. Bot. Zeitschr., vol. $1 x$, I9IO.

\section{DESCRIPTION OF PLATE XXIX.}

$l=$ lenticels $; r_{0} t_{0}=$ root-tip $; r_{0}=$ root $; n_{0}=$ nodule $; \quad v_{0} b_{0}=$ stele $; g \cdot p_{0}=$ meristematic apex $; p_{0}=$ phellogen $; f_{0}=$ cortex $; b_{0}=$ cells containing bacteria $; a_{0}=$ loose outer cells; $c_{0}=$ periderm $; B \cdot r_{0}=$ Bacillus radicicola $; A z .=$ Azotobacter $; A n_{0}=$ Anabaena $; s_{0}=\operatorname{starch} ;$ $0 .=$ calcium oxalate.

Fig. I. Roots of Cycas circinalis, some $\left(n_{0}\right)$ negatively geotropic owing to infection with Bacillus radicicola. Nat. size.

Fig. 2. Root-nodules of Cycas circinalis. Nat. size.

Fig. 3. Root-nodules of Encephalartos Hiddebrandtii. Nat. size. (a) large tip without an algal zone; (b) branched nodule without an algal zone; (c) cluster with zone developed. Nat. size. Nat. size.

Fig. 4. Root-nodules of Stangeria Schizodon (a) without algal zone; (b) with algal zone.

Fig. 5. Root-nodules of Zamia Lindeni. Nat. size. 
Fig. 6. Root-nodules of Macrozamia Macleyi. Nat. size.

Fig. 7. Root-nodules of Ceratozamia mexicana. Nat. size.

Fig. 8. Root-nodules of Dioon spinulosum (a) spherical masses and large swollen tip; (b) with algal zone present. Nat. size.

Fig. 9. Part of longitudinal section of nodule of Encephalartos without an algal zone. $\times 70$.

Fig. Io. Portion of the algal zone of the nodule of Encephalartos. $p_{0}=$ papillate cells. $n_{.}=$nucleus. $\times 325$.

Fig. II. Part of longitudinal section of nodule of Encephalartos with an algal zone. $g_{\bullet}=$ gap in algal zone by lenticel ; $E .=$ end of algal zone. $A . Z$. algal zone. $\times 35$.

Fig. 12. Part of longitudinal section of nodule of Stangeria showing the basal ridge of tissue $=b . r . \quad \times 35$.

Fig. I3. Portion of a longitudinal section of nodule of Stangeria with enclosed areas of Bacteria and Algae. $\times 70$.

Fig. I4. Part of longitudinal section of root and nodule of Dioon, showing mass of fan-shaped parenchyma $=b$. at base of nodule; $m_{\bullet}=$ meristematic tissue $; t_{\bullet}=$ tannin. $\times 35$. 


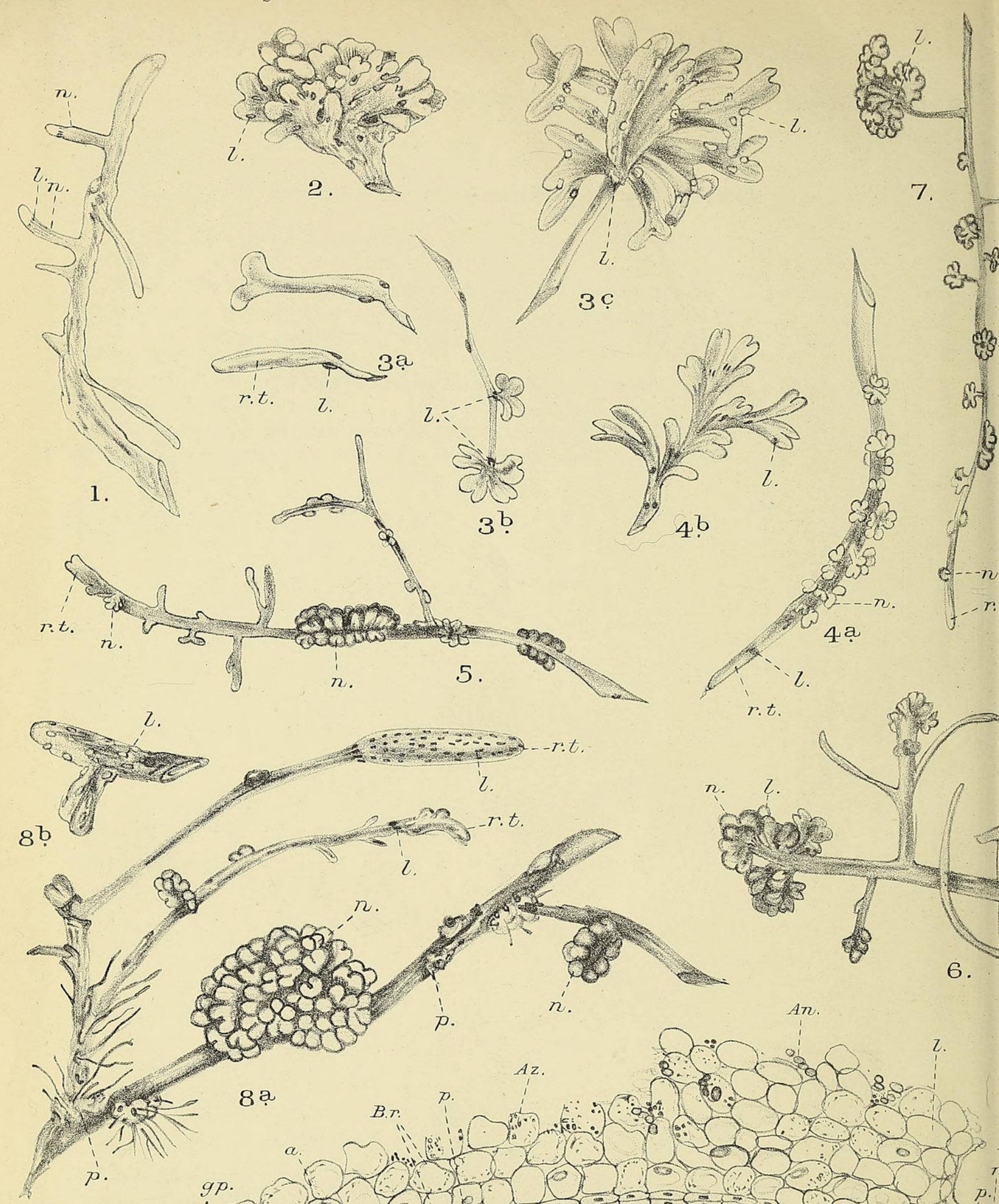


Antials of Botany
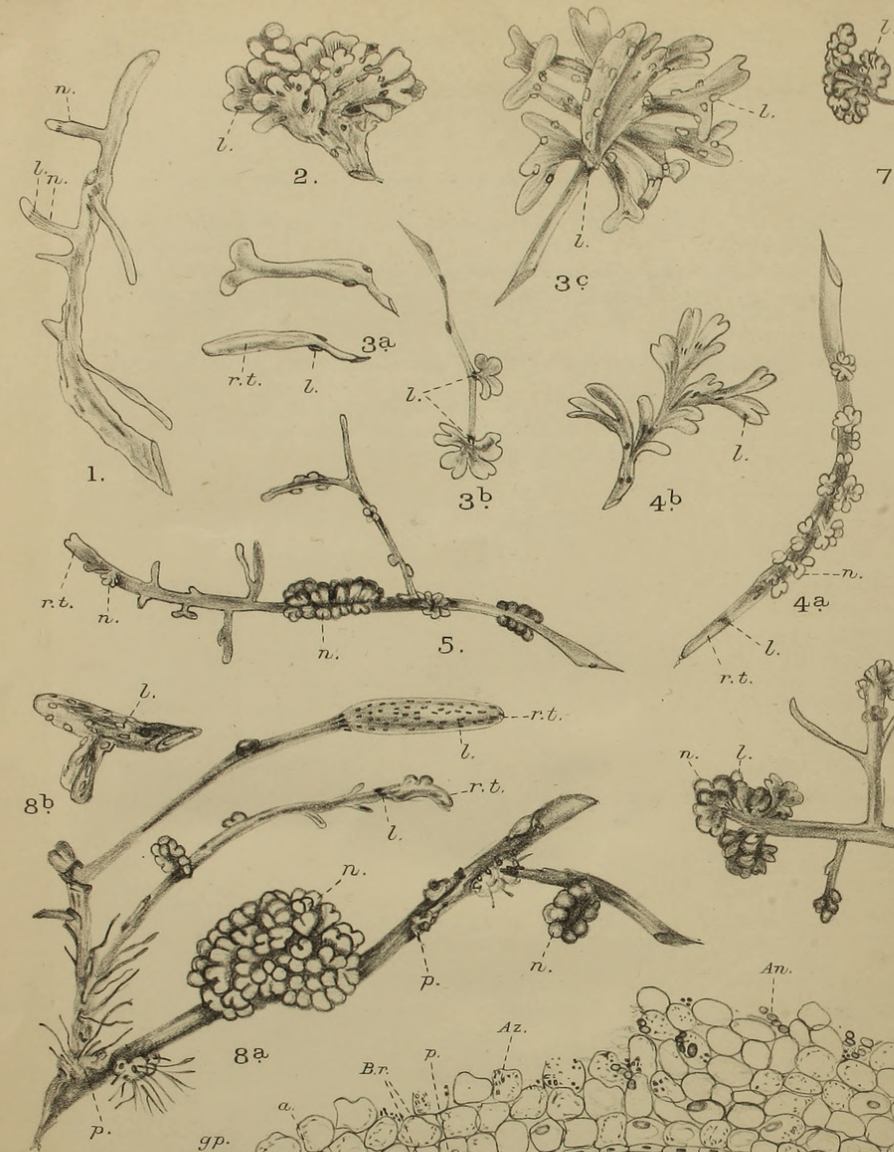

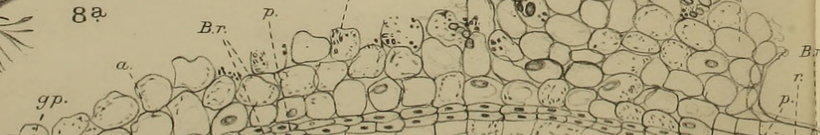

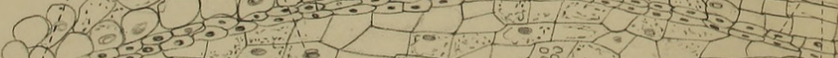

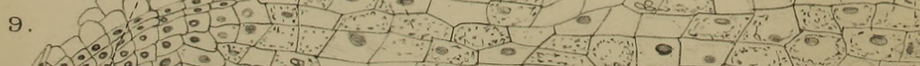

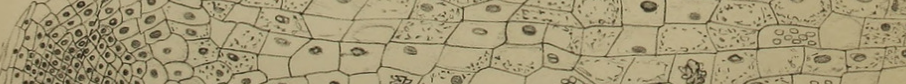

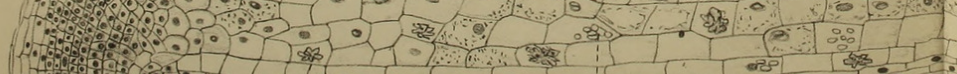
7月o E.R.Spratt del.
An. Br:Az

VoL.XXIX,PL.XXIX.

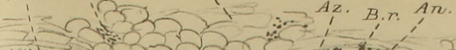

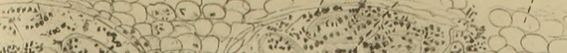

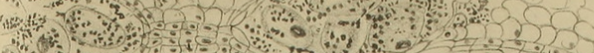

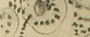

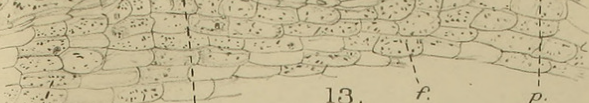

हैं

है?

,

की

$y^{3}$
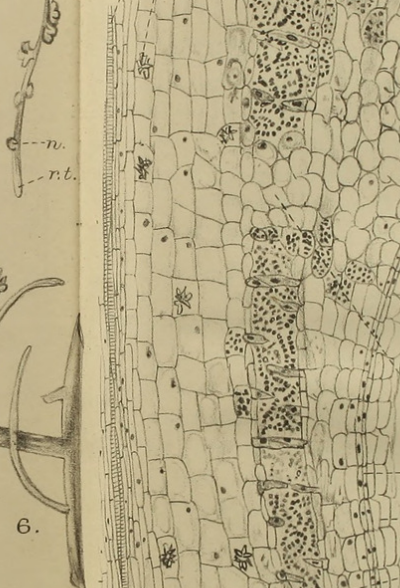

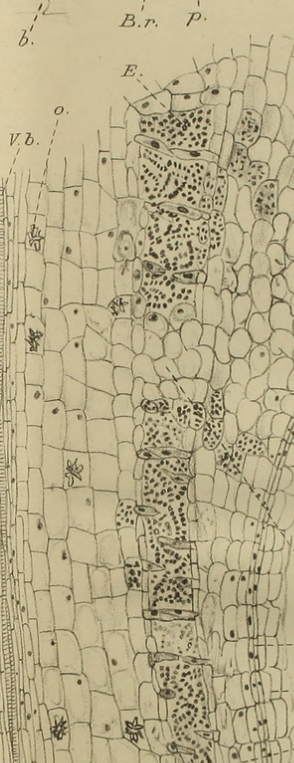

13

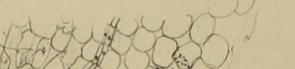

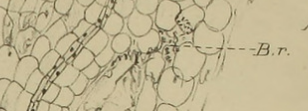

(2)

2. 1

11 .

i. 2 ?

int

$2,03^{4}$

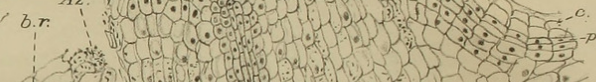

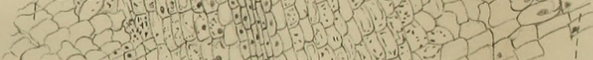

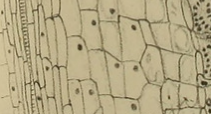

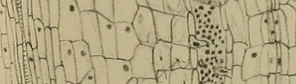

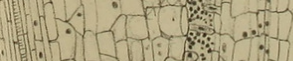

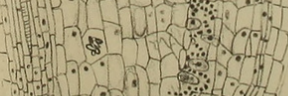

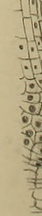

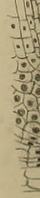

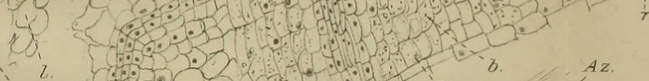
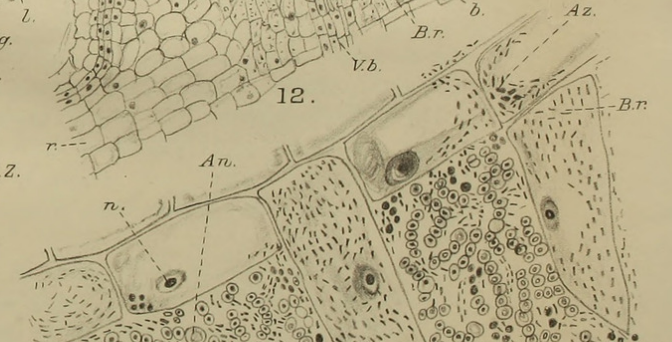

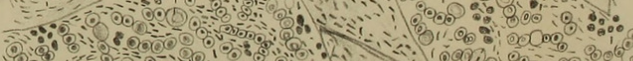

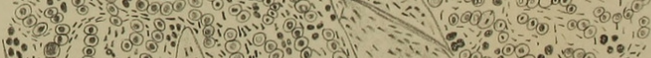

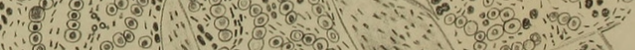

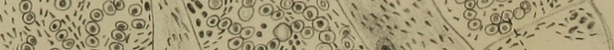
8. $1.000 \%$

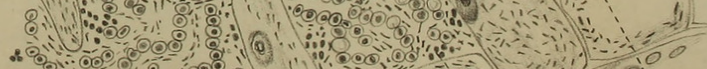
00000.0.

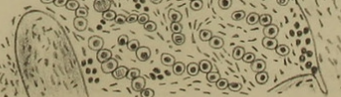

10.

Huth Iith, et imp. 


\section{$2 \mathrm{BHL}$ Biodiversity Heritage Library}

Spratt, Ethel Rose. 1915. "The root-nodules of the Cycadaceae." Annals of botany 29, 619-626. https://doi.org/10.1093/oxfordjournals.aob.a089570.

View This Item Online: https://www.biodiversitylibrary.org/item/243629

DOI: https://doi.org/10.1093/oxfordjournals.aob.a089570

Permalink: https://www.biodiversitylibrary.org/partpdf/320087

\section{Holding Institution}

Smithsonian Libraries

\section{Sponsored by}

Biodiversity Heritage Library

\section{Copyright \& Reuse}

Copyright Status: Not in copyright. The BHL knows of no copyright restrictions on this item.

This document was created from content at the Biodiversity Heritage Library, the world's largest open access digital library for biodiversity literature and archives. Visit BHL at https://www.biodiversitylibrary.org. 